\title{
Introduction of Environmental Protection Concept in Textile Major Education
}

\author{
Congcong $\mathrm{Pu}^{1}$ Boshan Gao ${ }^{2}$ Xinyu $\mathrm{Chen}^{3}$ \\ 1.Lutai school of Textile and apparel, Shandong University of Technology, Zibo, Shandong, 255049, China \\ 2.Zibo Shang He Textile CO.LTD, Gaoqing, Shandong, 256300, China \\ 3.Lutai school of Textile and Apparel, Shandong University of Technology, Zibo, Shandong, 255049, China
}

\section{ARTICLE INFO}

Article history

Received: 26 February 2021

Revised: 28 February 2021

Accepted: 9 April 2021

Published Online: 16 April 2021

Keywords:

Environmental protection concept

Textile major

Training programs

\begin{abstract}
The textile industry is a pillar industry of the national economy, and it is also a polluting industry. Green environmental protection has become the development trend of the textile industry, which requires the joint efforts of the government, enterprises and practitioners. Strengthening the environmental protection education of textile students has important significance for the implementation of sustainable development strategy of textile industry. Tertiary education is a very good platform for the implementation of environmental protection education for textile students, and it is also a critical period for students to strengthen the concept of environmental protection education. Students' environmental protection awareness may take measures to cultivate such as integrating environmental protection courses into major training programs, practice teaching of environmental protection, applying for training programs of college students' innovation and entrepreneurship, participating in research projects, etc.
\end{abstract}

\section{Introduction}

Textile industry is the traditional pillar industry of China's national economy and an important livelihood industry. It also plays an important role in prospering the market, expanding exports, absorbing employment, increasing farmers' income and promoting the development of urbanization. At the same time, textile industry has become the world's second largest pollution industry, after the oil industry. At present, the textile industry has become the world's second largest water consumption industry, and each year produced about $20 \%$ of the global waste water. In addition, the greenhouse gas emissions of the textile industry have exceeded the total emissions of internation- al flights and maritime transport. Green environmental protection has become the development trend of the textile industry, which requires the joint efforts of the government, enterprises and practitioners. At present, many textile companies are increasing technological innovation, expanding environmentally friendly production lines, and enhancing their product competitiveness by reducing pollution and using environmentally friendly chemical processes. Environmental protection issues in the textile and apparel industry are becoming increasingly severe, and more and more consumers have a growing awareness of environmental protection. Green and environmentally friendly products are more attractive to consumers. Training textile talents is the guarantee of building mod-

*Corresponding Author:

Congcong Pu,

Lutai school of Textile and apparel, Shandong University of Technology, Zibo, Shandong, 255049, China;

E-mail:14948962@qq.com. 
ern green textile industry. Therefore, strengthening the environmental protection education of textile students has important long-term significance for the implementation of sustainable development strategy of textile industry ${ }^{[1-5]}$.

\section{Environmental Problems in Textile Industry}

As is known to all, the textile industry is a high energy and water consumption industry. Especially the printing and dyeing process is accompanied by a large number of chemicals in the solution, so the pollution caused by the printing and dyeing industry is very serious. According to statistics, it takes about 2,700 liters water to produce a cotton shirt and about 7,500 to produce a jeans. In order to make the fabric better color, touch, durability and reliability, the use of chemical dye solution is becoming more and more complex, resulting in more and more complex components in the waste water, which greatly increases the difficulty of treatment. The air pollution caused by textile industry mainly comes from boiler combustion and the emission of VOCs. Printing and dyeing process generally need to be carried out in high temperature environment, which will lead to VOCs emission. These gases pose a serious threat to the health of workers and the surrounding living environment. Solid waste pollution from printing and dyeing industry includes many hazardous waste besides general solid waste. The noise pollution of textile industry is mainly caused by machine operation. Old clothes handling has also become part of environmental problems. According to the data of China Circular Economy Association, about 26 million tons of old clothes are thrown into the dustbin every year in China, and this data will increase to 50 million tons after 2030. At present, most of the used clothes are still treated by landfill or incineration, and these two methods will cause serious environmental pollution. At present, many enterprises have realized that green environmental protection will be a new trend for the development of textile and garment enterprises. Most textile and garment enterprises also attribute environmental protection to corporate social responsibility, and they want to alleviate environmental problems from production materials and environmental investment.

\section{Introduction of Environmental Protection Concept}

The concept of green environmental protection has become the development trend of the textile industry, which requires the joint promotion of government, enterprises and practitioners. Colleges and universities are the cradle of cultivating professional talents in the future. Therefore, strengthening the environmental protection education of textile students is of great long-term significance for the development of green textile industry and the implementation of sustainable development strategy of textile industry. From the current situation of environmental protection education of college students in China, college students generally have insufficient knowledge of environmental science and technology, poor awareness of environmental protection. Those cannot meet the needs of the sustainable development strategy of environmental protection. In view of the situation and the status of textile industry in national economy, it is of great practical significance to carry out environmental protection education related to textile majors in colleges and universities ${ }^{[6-9]}$.

\subsection{Integrating Environmental Protection Cours- es into Major Training Programs}

Tertiary education is a very good platform for the implementation of environmental protection education for textile students, and it is also a critical period for students to strengthen the concept of environmental protection education. In view of the fact that the textile industry produces substantial pollution, pollution control courses must be incorporated into major training program. At present, few colleges integrate environmental protection courses into major training programs, and textbooks related to environmental protection for textile majors are too few. Since the pollution of textile industry comes from many aspects of production, so in the teaching program, teachers will involve environmental protection content such as environmental protection new technology and environmental protection additives and other knowledge into the teaching. Students initially establish the concept of environmental protection, realize the importance of environmental protection. Teachers should make full use of basic courses, compulsory courses, elective courses, lectures and teaching-related environmental education on environmental protection, professional practice and social practice to carry out environmental protection education timely $^{[10-12]}$.

\subsection{Cultivating Students' Environmental Protec- tion Awareness}

At present, the textile industry practitioners' awareness of environmental protection is relatively weak. Although some practitioners recognize the importance of environmental protection, due to the high cost of environmental protection materials, the price of environmental protection products of textile and garment is relatively high. At the same time, the majority of consumers do not have enough understanding environmental protection products, which 
makes the market of environmental protection products too small. Eventually, some manufacturers are reluctant to produce green products, and even abandon the green environmental awareness in the production of textile and garments. In the future, college students' environmental awareness has a great decisive role in the development of the textile industry. However, China's green environmental education is not universal enough, in order to make environmental education better need to focus on tertiary education. Strengthen the textile and garment majors students' green environmental education and sustainable development consciousness, which are being increasingly urgent ${ }^{[13-14]}$.

\subsection{Practice Teaching}

Practice teaching occupy a large proportion in the teaching of textile major. It is the best way for teachers to implement environmental education for students. Practical teaching can be conducted in many ways, such as establishing a green textile education base, setting up green environmental protection projects to students, etc. Teachers can also guide students to actively apply for training programs of college students' innovation and entrepreneurship related to environmental issues in textiles, or encourage students to participate in textile industry research projects related to environmental protection, guide students to solve textile environmental problems through research projects, and further cultivate students' ability to solve problems and scientific research ability. Colleges and universities can also set up clothing green environmental protection design competitions to attract students to participate and cultivate their environmental awareness.

\section{Conclusion}

Under the influence of the environmental storm, textile printing and dyeing enterprises have encountered difficulties. Only those enterprises that attach importance to environmental protection work and meet environmental protection standards can produce and develop normally. The 13th Five-Year Plan for National Economic and Social Development of the People's Republic of China clearly points out that in 2020 , the energy consumption of unit industrial added value of the textile industry enterprises will decrease by $18 \%$, the carbon dioxide emission intensity will decrease by $22 \%$, the water consumption will decrease by $23 \%$, and the total amount of recycled textile fibers will reach 12 million tons. In today's situation, enterprises can survive only if they deal with environmental issues well. For advantageous enterprises, the environmental protection storm actually provides a good opportunity to accelerate development and accelerate transformation, which can better promote the enterprise economic development and environmental protection. Textile industry is an industry that has a significant impact on the environment. At the same time, textiles are closely related to people's daily life, more and more consumers are also growing awareness of environmental protection. At present, there is still a big blank area for students' green textile education in colleges and universities in China. Textile major environmental protection education makes green education enter the classroom, so that students realize that there are many problems to be solved in the field of textile, which are closely related to our living environment. To create various practical opportunities for students, let them invest in the practice of creating green textiles in the future, cultivate their environmental protection awareness and creative thinking ability, and cultivate talents for accelerating the pace of green textiles in China.

\section{References}

[1] Palmos Dimitrios, Papavasileiou Christina, Papakitsos Evangelos C., et al. Enhancing the environmental programmes of secondary education by using webtools concerning precaution measures in civil protection: The case of Western Attica (Greece). 2021:135.

[2] Guo Jiahua, Liu Shan, Zhou Li et al. Prioritizing pharmaceuticals based on environmental risks in the aquatic environment in China[J] Journal of Environmental Management, 2021: 278.

[3] Yihang Lv,Jingjing Kong,John Williams. Research on the Education of Environmental Protection Concept of College Students after the Epidemic[A]. Wuhan Zhicheng Times Cultural Development Co., Ltd. Proceedings of 6th International Symposium on Social Science (ISSS 2020)[C].Wuhan Zhicheng Times Cultural Development Co., Ltd.,2020:5.

[4] Environment - Environmental Protection; New Findings from Department of English Education in the Area of Environmental Protection Described (An analysis of multimodal resources in environmental protection posters). 2020:716-719.

[5] Niklas Harring, Sverker C. Jagers, Simon Matti. Higher education, norm development, and environmental protection. 2020, 79(2):291-305.

[6] Xiaoyue Zhang, Wangbing Shi. On the Integration and Innovation of the Ideas of Environmental Protection and Ecological Civilization in Ideological and Political Education in Colleges and Universities. 2019, 2(4):18-20.

[7] Environment - Environmental Education; Study 
Findings on Environmental Education Are Outlined in Reports from S.X. Theosemni and Colleagues (The Protection of the Environment As Applied To the Environmental Education Programme of the Holy Monastery of Chrysopigi, Crete). 2019:1270-1275.

[8] Sister Theosemni. The Protection of the Environment as Applied to the Environmental Education Programme of the Holy Monastery of Chrysopigi, Crete. 2018, 70(4):751-757.

[9] Krajewski Michael P, Lu Chi Hua, Stellrecht Elizabeth, et al. An environmental scan of pharmacists supporting pre-doctoral dental education institutions, 2020.

[10] Seaman Jayson, Dettweiler Ulrich, Humberstone Barbara, et al. Joint Recommendations on Reporting
Empirical Research in Outdoor, Experiential, Environmental, and Adventure Education Journals. 2020, 43(4):348-364.

[11] Melissa Barnes, Debra Moore, Sylvia Christine Almeida. Empowering Teachers through Environmental and Sustainability Education: Meaningful Change in Educational Settings. 2021.

[12] Hui Luan, Tung-Lin Li, Min-Hsien Lee. High School Students' Environmental Education in Taiwan: Scientific Epistemic Views, Decision-Making Style, and Recycling Intention. 2020:1-20.

[13] Mohamed Abioui, Monica Maria Axini, Dan Razvan Popoviciu, et al. Review of Environmental education and ecotourism by Fernando Ramírez and Josefina Santana. 2020:1-4. 